\title{
Community and socio-economic impact of corporate purchase of water: lessons from Australia
}

\author{
J. Edwards ${ }^{1}$, H. Bjornlund ${ }^{1,2}$ \& B. Cheers ${ }^{1}$ \\ ${ }^{1}$ University of South Australia, Australia \\ ${ }^{2}$ University of Lethbridge, Alberta, Canada
}

\begin{abstract}
The introduction of water markets has caused widespread concern within irrigation communities both among irrigators and among other community members. There are two main areas of community concern. The first is associated with the export of water out of a certain location and the second is associated with the consolidation of water into larger corporate entities. This paper investigates the second area of concern. The analyses are based on extensive interviews with key informants within a community in South Australia dominated by the wine and other horticultural industries. Following the introduction of water markets this area has seen the emergence of a large number of new corporate entities or substantial expansion of existing family operations evolving into large family corporations.
\end{abstract}

Keywords: water market, water trading, community impact, socioeconomic impact, corporate farming.

\section{Introduction}

Most areas with intensive irrigation are located in semiarid regions approaching or exceeding sustainable levels of extraction for consumptive uses. Nonirrigation demands for water continue to increase and the value society places on the environment also changes, which results in increased pressure to leave more water in the rivers for environmental purposes. Irrigation in these regions often accounts for $70-80 \%$ of total water use; hence the irrigation sector is inevitable going to be pivotal in meeting this new demand. Hence, there is an increasing pressure to reallocate irrigation water to meet these growing needs. To minimize 
the socioeconomic impact of reductions in water availability for irrigation it has also been argued that water needs to be reallocated to the most efficient and highest value producers. Water markets have increasingly been promoted as the instrument to facilitate such reallocations of water.

The introduction of water markets has caused widespread concern within irrigation communities both among irrigators and community members. One centres on the export of water out of a certain location with accompanying fears that it will result in fewer on and off farms jobs, leading to population loss. This will in turn result in loss of businesses, services and community cohesion. Also, if water is traded off farms then their value is reduced, this will result in declining land values and decreasing revenues for local council. Reduced revenue can either be met by lowering the level of services or by increasing council rates for other land owners - or both.

Individual irrigators within irrigation districts are also concerned about the impact of trading out of districts due to its impact on water prices and security of future supply. In settings like Australia, where water charges are set at a full cost recovery basis, less water left in the system results in higher water charges per unit as the cost of supply is largely fixed. In the end, if export of water continues some supply systems might end up being closed down. These concerns have previously been investigated and reported in the literature [1,2]. A second concern centres on the emergence of corporate farms as a result of the operations of water markets.

The use of the term 'corporate farms' or, as our respondents most frequently deemed them, 'corporates' emerges from the way they defined them. 'Corporates' were defined as large-scale enterprises with two salient characteristics; they are not family owned and they are not perceived to have 'roots' in the community. Some of our respondents acknowledged some 'grey' areas about what constituted a 'corporate'. For instance, one large company with a national and international reach was still heavily associated with the family that had instigated it and was regarded as still having an interest in the long-term future of the region. In the opinion of some, but not all, respondents this company did not constitute a 'corporate'. Enterprises that were part of managed investment schemes or were local branches of national or trans-national companies were unanimously identified as 'corporates'. They were not regarded as part of the local community and were perceived as having little loyalty to the long-term future of the region.

This paper reports on that concern, based on extensive in-depth interviews with key stakeholders within the Riverland of South Australia. It reflects the observations, knowledge, perceptions, values and beliefs of the people we interviewed. It does not provide an objective discussion of the impact of corporate farming or attempt to judge or verify the accuracy of their views. For a full report on the findings from this research see [3].

\section{Background}

The case-study community (Loxton) is set within the Riverland of South Australia, which is Australia's largest horticultural area. Despite its productivity, 
the Riverland region is barren country, described by one informant as 'an irrigated desert'. The area only receives an average rainfall of approximately 250 $\mathrm{mm}$ per year. The agricultural industries in the region thus depend on irrigation. Post first and second-world war water policy in South Australia was driven by a development imperative; the attempt to tailor new projects to fit with environmental concerns did not have a place in the world view of the time [4]. For instance, in the Riverland the development of irrigation went hand-in-hand with the handing out of blocks to returning soldier settlers and post-war immigrants. Traditionally irrigation in the Riverland has therefore been based on small family farms known locally as 'blockies'.

By the 1980s, the emphasis had shifted from state-sponsored development to economic rationalism and the operation of the market was given much greater reign. Water became less a public good than a commercial commodity and the water market were introduced in 1984 on the assumption that it was the most efficient way to facilitate the allocation of water in contexts where no new supplies were forthcoming. However, by 1994 it was clear that the health of the Murray Darling Basin (MDB) was threatened by excessive water extraction. The Council of Australian Governments adopted a framework to arrest the declining health of the MDB. One key strategy was the extension of water markets. Building on earlier reforms, CoAG decided in 2003 to extend the operation of water markets by removing impediments to trade of water across districts and states. The premise was that by allowing market value to attach to water, people (primarily agricultural users) will use it more efficiently [5, 6]. It was assumed that trading of water would; i) direct it towards areas with suitable soils and other favourable environmental conditions and away from areas with unsuitable characteristics and thereby lessen the environmental impact of irrigation; and ii) move it away from inefficient users, who produce low-value commodities, to users who make efficient use of water and produce high-value commodities. Such reallocation, according to this logic, would increase the economic output from scarce resources and thereby lessen the socioeconomic impact within the affected communities of reducing extraction of water for consumptive use.

There has been a small corporate presence in the Riverland for a few decades, although they expanded their operations there in the 1990s. This research thus sits in the context of expanding corporate presence and a profound and longstanding drought. Prior to 2006, irrigators in the Riverland never received less than $100 \%$ of their entitlement. However since then it has never reached $100 \%$; it was $60 \%$ in $2006 / 07 ; 32 \%$ in $2007 / 08$ and $18 \%$ in $2008 / 09$. In addition, the region has in recent history suffered from low commodity prices for some of its key products and sky rocketing prices in the water market. The Riverland stands on the brink of an economic and environmental crisis and the perceptions and opinions about the community effects of the corporate purchase of water cannot be understood apart from this context.

\section{Corporate purchase of water}

Given the centrality of water to the Riverland, anything perceived to negatively influence its availability and price is likely to be regarded with hostility. The 
prevailing opinion is that, notwithstanding the drought, corporate enterprises play a large part in low allocations and high market prices for water. With much less water available, the dominant perception is that corporate enterprises have the capacity to buy water, while small growers do not. Hence, people with small holdings are being denied water because corporates are buying most of what is available. Richard sketches a perception we heard repeatedly:

Obviously the resources of water becoming a lot scarcer, it has been a significant issue in terms of perceptions of corporates being... resourced up and buying the water and the perception is that they're getting it and the smaller growers aren't.

Some of our respondents also believed that the shortage of water was due to over-allocations rather than drought and sheeted home the responsibility to the seemingly unbridled capacity of 'corporates' to buy water. This finding has been replicated by other sources [7]. According to Lisa, 'It is not the lack of rain, it's not that we are having a drought, it's not the dry - it's so many people pulling off from the river and it has been poorly managed'. Richard relates that many people share Lisa's concern that low water levels in the river and uncertain water supply can be laid at the feet of local corporate enterprises:

And very much there is the finger pointing, the blaming of the corporate and the managed investment funds as a very big part of the issue of the over-allocation of water ... talking about here that the river is a finite resource and it has been over allocated, and the feeling is that the corporates, because of their huge plantings, are a big part of that over allocation.

In the face of low water allocations many small block owners have made the difficult decisions to let citrus trees die or cut them back so severely that they will not bear fruit again for several years. These decisions are difficult ones, causing much distress. This is compounded by the sight of contiguous new plantings by corporate enterprises that appear to be well-watered and maintained. Grant relates the dominant sentiment among community members:

... the whole crux of it is that given the water restrictions the locals are very, very upset, there doesn't seem to be any regulations. Somehow or other they [corporate enterprises] get licenses and continue to plant and the locals are thinking "well why would that be when we really are desperate for water"?

Bill, a local human service worker, comments on how the apparent juxtaposition between the dying orchards of local 'blockies' and the well-tended crops of corporate enterprises is generating some hostility:

But you definitely see that when the push comes to shove...blockies letting their trees die and just down the road the corporate is putting in acres and acres of new trees... the community sympathies are definitely going to lie with the locals and not with the corporates.

Some, but not all, of our respondents consider that prior to the onset of the drought and diminishing water allocations for irrigators, there was little concern with the presence of 'corporates'. However, the scarcity of water now leaves many community members feeling that small block owners and corporate 
enterprises have to compete for the amount that is available while the price of water has risen dramatically in the past year. The widely held belief is that corporate enterprises are better positioned to afford water. A second belief is that because of taxation laws and other advantages afforded them, corporate enterprises are far better placed to purchase water. Tom says, '...there is another tax benefit [for Managed Investment Schemes-MISs] in that leasing water is an allowable expense'. In Clark's opinion:

...they are able to buy water which is simply not able to be purchased by your average person involved in agriculture... Those who have dollars win, those who do not have dollars lose.

Not only can corporate enterprises afford to buy water, their presence, according to many of our respondents is driving the price of water up. In Harold's opinion:

Well, they've [corporates] got resources to buy the water. Because there has been so many hectares put in...the price of water, the cost of leasing the water has just skyrocketed....

Mike, a local block owner, voices his frustration at the greater capacity of corporates to buy water:

And that is the other thing that stinks, you know like corporates or whatever they are probably are buying water, they can afford it. But I'd like to go out and buy $\$ 50,000$ of water just to get my crops ready.

Lisa points to another source of discontent among local growers; for corporate enterprises, water can simply be another asset, while for block-owners, it is their business' lifeblood:

... water has become a tradable commodity now... So those people who are going to be cashed up, which are going to be corporates, definitely they would have to be looking at the water market and buying. Of course that is going to affect the small grower because it ups the price. They [corporates] don't have to worry about it at all, they can just sit on their water. They don't even have to use it... I heard that [company name] was investing in water... So here we are, small growers, wanting this water to keep our livelihood alive and into the future and there is this water sitting there as an asset on somebody's books.

Stuart also outlined how small growers feel that they face very different pressures than those faced by corporates:

Because an investment property [isn't] necessarily driven by profits and therefore growers feel certainly that they are competing on an unlevel playing field etcetera. They are obviously driven by profit and that is what they do to put bread and butter on the table and they don't feel that it is fair comparison I guess. They are competing in the same market place but it's two different quotas.

Others articulated a related belief: that achieving a profit is not as crucial to corporate undertakings as it is to small block owners. Stuart, like many people, considers, "so private temporary water happens to be \$1,200.00 a meg [megalitre], there are more tax deductions". Clark argues that, '...the super funds [retirement funds] that plant up these huge areas aren't here to make a 
profit really and the locals know that...' Mike offers a similar perspective, that corporates do not face the same imperative as small owners to make profits, 'Yeah well I guess they don't have to show a profit because a lot of it is just tax break isn't it....? Warren also relates another refrain heard frequently in relation to corporates; that is, if the economic situation in horticulture starts to crumble, the effects on corporate enterprises are not nearly as devastating as they are on small block owners:

...if the market goes bad... [corporates] can at least walk away and say sorry to your investors... I guess what the blockies are saying is that ... it's okay for them [corporates] to come in and make a mess of things and get out again if the situation doesn't suit them, but in the meantime [the corporates have] left all of us in your wake....

Many of our respondents consider that the real challenge to the economic vibrancy and sustainability of their community and the Riverland in general is not the drought, but the presence of corporate enterprises in their region. Another study found that the growers they interviewed felt that the structural conditions of their industry, conditioned in large part by corporate enterprise rather than the drought, was their primary burden [7].

\section{Corporates and market balance}

The new plantings of corporate enterprises anger local people not only because of an apparent inequity in the capacity to access water, but because these plantings are regarded as distorting the market, making profitability even harder for small block owners. There is evidence that supports the concerns of our respondents. In July 2008, the Wine Grape Council of South Australia identified almost 800 ha of new vine plantings by Managed Investment Schemes throughout the Murray-Darling Basin; an 80 ha estate is currently being developed near Loxton. (The Australian July 17 2008). In the context of new corporate plantings, Grant relates how local people are frustrated that these new plantings are occurring when there is already a glut:

We had a Riverland rally back here, oh, it was over twelve months ago ...

it was over and over again "why are you letting these big corporations continue to plant when you see we've got a surplus of grapes"?

Corporate enterprises are regarded as distorting the market that had operated effectively for small block owners, generating some hostility on the part of local community members. Richard tells how corporate enterprises are regarded as taking over market share. The hostility to what is regarded as distortion of the market by the actions of corporates was documented in a study commissioned by the Riverland Socio Economic Study Steering Committee [7]. The water shortage has intensified this hostility, in Richard's opinion:

I guess there has just been the normal anti-big business type of feeling.

But definitely since the water issue has become... and I guess in the grape situation since the oversupply, where a lot of that was blamed on corporates... Managed investment funds where people could see plantings going in all over the place, and the fact that they were planting 
for perhaps different reasons ... well quantity rather than quality and that's where the growers here particularly in the grapes, have been pinching in their market.

Lisa pointed to an apparent paradox that many people rose during fieldwork; if there is an over-supply of certain commodities, why are corporate enterprises undertaking large plantings of them? The perception that corporates are undertaking fresh plantings adds to a generalized uncertainty about the future and the hostility towards corporates, heightening unease about them and their actions:

I think along the Murray-Darling Basin, thousands of acres of citrus [are being planted by corporates]. ... people have to ask questions and say "How does that work". When growers here cannot make a dollar out of citrus growing, but all of a sudden there is another thousand [acres planted], because they say there is an oversupply, the packers won't take them, because you don't need them, all of a sudden there is just... [company name] last year planted up thousands of acres of citrus. So where is the balance? What is going on there?

Mike, a grower, considers that corporate agriculture has a place in the overall agricultural profile, but he reveals a certain bitterness that, in his opinion, small block owners do the hard work of getting an industry established. Then corporates enter the market and make easy profits without having taken the risk and doing the hard work involved in establishing the industry. Similar sentiments have been voiced elsewhere [7, pp. 39-41]. In Mike's words:

... what I think annoyed us the most is that they [corporates] come out on the back of good times. Like "here is a good thing, let's jump on it" and the guys like us that have been here most of our lives, worked hard to build our property and we built the industry you know.

Tom also resents the fact that it was the small-to-medium size block owners, he argues, that created a viable and productive grape and wine industry in Australia. Corporate undertakings and managed investment schemes entered the field after small growers had made it profitable; now they threaten its viability:

... what they are doing progressively is putting the squeeze on those who have developed a region, that have been efficient and have been very profitable until the oversupply that was created by the overdevelopment.

\section{Contracts}

An issue that generates a considerable degree of chagrin among growers and general community members is the contracts given to local growers by some large corporate enterprises [7]. There was a widespread perception that they foisted unfair and unethical contracts on growers, who had little option but to accept. Lisa's comments encapsulate a sentiment we heard frequently:

So then the company basically said to them "we can't take your grapes because of the oversupply but you can't sell them anywhere else”. So growers were stuck. They [the winery] also paid a very low price... there was a clause in the contract to say that if the growers had an issue 
with prices.. paid they can go to a third party that was agreed upon by both the growers and [the company] and whatever that third party said that they had to sort of abide by... well [the company] didn't do that.

Current evidence also indicates that the flooding of the market for wine grapes, in combination with declining demand for certain grape varieties, is driving down the prices paid to growers for some kinds of grapes. In the Riverland, growers producing chardonnay have been warned to expect payment of $\$ 300$ a tonne; the report in The Australian (July 2008) concludes that this is not a viable price for many growers: "With the price of irrigation and fertiliser soaring, this would not cover costs for most growers" [9]. Warren, a local health worker, comments on how 'bad' contracts translate into personal problems, 'So we saw a lot of distress with bad contracts and with people who had borrowed and struggled then to make ends meet'.

Grant recalls how the low prices paid for grapes during the glut of a few years ago led many growers to sell their properties:

They were obviously wanting to get out because back then when we had the grape surplus there were over fifty odd blocks that were actually listed for sale, but there were a lot more that would have sold to someone who had come along....

Lisa, however, suggests that overall the contracts that were being offered in late 2007 are an improvement on those offered several years ago:

...because there is such a shortage of the grapes, the wineries have come out and promised us certain prices... this is unprecedented, and at this time of the year, in fact it was back in September, the wineries came out and gave us prices for next vintage. Usually they do it from about January... This year they have done it so early because they are scared they are not going to have grapes go through their winery. So they are saying to us "We will guarantee these prices", which are anywhere between umm...250 to 500\% higher than what we have been paid for the last two seasons.

Jeffrey, however, reveals that even though in the current environment the contracts for grapes offer growers reasonably good prices, many growers juggle a degree of uncertainty occasioned by contracts. Having signed contracts, growers are expected to supply the grapes even if the harvest fails and this can lead to a degree of unpredictability that many find stressful. Jeffrey explains:

They [corporates] actually started [offering contracts] late September which is quite extraordinary... Now that's fantastic in one sense because the grower can say "okay, I'm going to get $\$ 600$ a ton for my shiraz and which is double what I got last year". However, at the same time the grower will think the price of water is going to continue to go up. I don't know what's going to happen over summer .., I don't know what's going to happen with temperatures and all the rest of it. I may not be able to buy more water in, my crop may then fail. I'm contracted to the winery to provide them and with a lot of those contracts you either have to find alternate grapes and provide them to them or you have to pay whatever it is you have contracted to them... And the other thing is the farmers think 
"gee, if the winery wants to buy my grapes right now for $\$ 600$ a ton, I might get $\$ 900$ in January or I might get $\$ 1,000$ in January. If it's a really hot summer and the crop completely falls over, I might get $\$ 1,200$ in February if I contract then". So it's not quite as easy or as simple as one might think - okay I've got a contract, fantastic. So it is a bit more difficult than that.

Jeffrey goes on to make a point that we heard frequently; primary producers are now 'price-takers' rather than 'price-setters'. The presence of corporates is linked to this new, passive role for primary producers. In Jeffrey's view:

...but now that the corporates come into town, we don't have as much freedom as to where we sell any more and they dictate to us much more in regard to the price we're getting, so those involved in agriculture once again are becoming even more so price takers rather than price setters because they don't have as much choice any more.... the larger corporate is able to say to those involved in whatever kind of industry they're in, "this is the price we're offering, if you don't provide to us at this price... we can go get it from 100 kilometres down the road, or we can actually get it from interstate or if we're large enough, we'll just buy the stuff in from overseas"

John acknowledges variability in the behaviour of corporate enterprises in relation to contracts; some are fair and reasonable, others are not. In John's eyes:

Depending on what contract you're talking about. If you look at the different contracts that are out there; [company] contracts, I mean the people with [company] contracts have really got through the last three or four years and they were very thankful they had a [company] contract. Other contracts with other wineries or other packers when times were tough, the growers have found out, they don't really mean a lot. Very hard to take a corporate on!

\section{Conclusion}

The transition from small family farms to larger 'corporate' type farms has accelerated in many areas dominated by capital intensive agriculture such as irrigated vineyards and other horticultural plantings. The Riverland of south Australia is no exemption. Recent extreme droughts and changing environmental values in Southeastern Australia combined with the introduction of water markets have accelerated this transition in the Riverland. This process has been of great concern throughout Southeastern Australia as many consider that this transition would ruin local communities and the heritage of small horticultural family farms on which the Riverland is based.

Many of our respondents consider that the practices of 'corporates' disadvantage the owners of small blocks, making profitable operation harder for them. They consider that corporate players distort the market, drive up the cost of water and enforce unfair contracts. All of these factors in tandem threaten the viability of family-owned blocks. Whatever the effects of corporate undertakings on the profitability of small block owners, opinion about the impact of the 
corporate presence on the local economy and society is much more mixed. Some believe that corporates bring investment and secondary industry into the regional economy, provide stable employment and lift the standard of agricultural practice in the region. Others regard them as having negative impacts on the local economy; by reducing the number of small family blocks, their spending within the local economy is reduced. Further, in the view of some, corporate enterprises are less likely to purchase local goods and services, also harming the local economy. Finally, some believe that corporate send their profits out of the local region [3]. There is considerable debate about whether the jobs created by corporate undertakings make up for the jobs that are lost through the loss of smaller, family-based blocks [3]. Likewise, there is no consensus about whether corporates provide much support for community based activities through various kinds of sponsorship [3]. Hence, there is a mixed evaluation about the contribution that corporate agricultural undertakings make to the vibrancy and sustainability of rural communities in ordinary circumstances.

\section{References}

[1] Edwards, J.; Bjornlund, H. and Cheers, B. (2007): The impact of trading of water out of districts: A case study of the Kerang region in Victoria. Industry Partner Report No. 5. ARC Linkage Grant Adelaide, University of South Australia. Available at www.waterresearch.net

[2] Fenton M (2006) The social implications of permanent water trading in the Loddon-Campaspe Irrigation Region of Northern Victoria, North Central Catchment Management Authority

[3] Edwards, J.; Bjornlund, H. And Cheers, B. (2008): Analysing community and socioeconomic impacts of corporate purchase of water - The Loxton area in south Australia, a case study. . Industry Partner Report No. 7. ARC Linkage Grant Adelaide, University of South Australia. Available at www.waterresearch.net .

[4] Hicks N and Harford J (2001) 'Water' in Prest W (ed) The Wakefield Companion to South Australian History. Wakefield Press, Adelaide.

[5] Tidsell and J and Ward J (2003) 'Attitudes toward Water Markets: An Australian Case Study' Society and Natural Resources 16: 61-75.

[6] Bjornlund H (2004) 'Formal and informal water markets - drivers of sustainable rural communities? Water Resources Research 40: W09S07.

[7] The Age (2007) The end of the family farm? November $24^{\text {th }}$

[8] RSEISC, Riverland Socio Economic Impact Steering Committee (2007) The Economic and Social Impacts of Key Industries on the Riverland, District Council of Loxton Waikerie.

[9] The Australian, 'Vineyards sour on tax schemes' July $17^{\text {th }}, 2008$. 